\title{
Human Development
}

Founded 1958 as 'Vita Humana’ by H. Thomae (1958-1981)

Former Editors: M.L. Langeveld (1963-1974),

B.L. Neugarten (1963-1969), K.F. Riegel (1970-1977),

W. Edelstein (1982-1987), J.A. Meacham (1977-1987),

H. Sinclair (1982-1987), D. Kuhn (1988-1996),

B. Rogoff (1997-2002), G.B. Saxe (2003-2006)

\section{Editor}

Larry Nucci,

Berkeley, Calif.

\section{Advisory Editors}

Marc H. Bornstein, Bethesda, Md.

Nancy Budwig, Worcester, Mass.

Ileana Enesco, Madrid Alexandra M. Freund, Zurich Cynthia Garcia Coll, Providence, R.I.

Artin Goncu, Chicago, Ill.

Bente E. Hagtvet, Oslo

Paul Harris, Cambridge, Mass.

Charles C. Helwig, Toronto, Ont.

Christine Howe, Cambridge Shoji Itakura, Kyoto

Melanie Killen, College Park, Md.

Charlie Lewis, Lancaster

Na'ilah Suad Nasir

Berkeley, Calif.

Katherine Nelson,

New York, N.Y.

Terezinha Nunes, Oxford

Willis F. Overton,

Philadelphia, $\mathrm{Pa}$.

Susan Rivera, Davis, Calif.
Barbara Rogoff, Santa Cruz, Calif.

Sylvia Rojas-Drummond, Mexico City

Martin D. Ruck, New York, N.Y.

Geoffrey Saxe, Berkeley, Calif.

Diana Slaughter-Defoe, Philadelphia, Pa.

Judith Smetana, Rochester, N.Y. Liliane Sprenger-Charolles, Paris

Elsbeth Stern, Zurich

Keiko Takahashi, Tokyo Michael Tomasello, Leipzig Elliot Turiel, Berkeley, Calif.

David C. Witherington Albuquerque, N.M.

Stella Vosniadou, Athens

Cecilia Wainryb, Salt Lake City, Utah James Youniss, Washington, D.C.

Philip Zelazo, Minneapolis, Minn. 


\section{S. Karger}

Medical and Scientific Publishers

Basel $\cdot$ Freiburg $\cdot$ Paris $\cdot$ London .

New York $\cdot$ Chennai $\cdot$ New Delhi

Bangkok $\cdot$ Beijing $\cdot$ Shanghai $\cdot$ Tokyo

Kuala Lumpur $\cdot$ Singapore $\cdot$ Sydney
Disclaimer

The statements, opinions and data contained in this publication are solely those of the individua authors and contributors and not of the publish er and the editor(s). The appearance of advertisements in the journal is not a warranty, endorsement, or approval of the products or services advertised or of their effectiveness, quality or safety. The publisher and the editor(s) disclaim responsibility for any injury to persons or prop erty resulting from any ideas, methods, instructions or products referred to in the content or advertisements.

\section{Drug Dosage}

The authors and the publisher have exerted every effort to ensure that drug selection and dosage set forth in this text are in accord with current recommendations and practice at the time of publication. However, in view of ongoing research, changes in government regulations, and the con stant flow of information relating to drug therapy and drug reactions, the reader is urged to check the package insert for each drug for any change in indications and dosage and for added warnings and precautions. This is particularly important when the recommended agent is a new and/or infrequently employed drug.

All rights reserved.

No part of this publication may be translated into other languages, reproduced or utilized in any form or by any means, electronic or mechanical, including photocopying, recording, microcopying, or by any information storage and retrieval system, without permission in writing from the publisher or, in the case of photocopying, direct payment of a specified fee to the Copyright Clearance Center (see 'General Information').

(C) Copyright $2014 / 15$ by S. Karger AG, CH-4009 Basel (Switzerland)

Printed on acid-free and non-aging paper (ISO 9706)

\section{KARGER}

Fax +4161306 1234 


\section{Human \\ Development}

No. 1

Editor's Corner

1 A Voyeuristic View of Possibilities and Threats: Neurosciences and Education

Lee, C.D. (Evanston, Ill.)

Original Paper

5 Human-Animal Interaction as a Context for Positive Youth Development: A Relational Developmental Systems Approach to Constructing Human-Animal Interaction Theory and Research

Mueller, M.K. (North Grafton, Mass.)

Commentaries

26 The Value of (Research on) Animals in Children's Lives. Commentary on Mueller

Severson, R.L. (Vancouver, B.C.)

30 Development and Human-Animal Interaction. Commentary on Mueller

Hurley, K.B. (Davis, Calif.)

Original Paper

35 Coming of Age in the Geospatial Revolution: The Geographic Self Re-Defined

Downs, R.M. (University Park, Pa.)

Commentary

58 Geospatial Tools and the Changing Nature of Human Spatial Thinking. Commentary on Downs Gauvain, M. (Riverside, Calif.)

\section{No. 2-3}

Learning by Observing and Pitching In to Family and Community Endeavors

Editors: Rogoff, B.; Alcalá, L.; A.D. Coppens, A. López, Ruvalcaba, O.; Silva, K.G. (Santa Cruz, Calif.)

69 Learning by Observing and Pitching In to Family and Community Endeavors: An Orientation

Rogoff, B. (Santa Cruz, Calif.)

82 Constellations of Cultural Practices across Generations: Indigenous American Heritage and Learning by Observing and Pitching In Rogoff, B.; Najafi, B. (Santa Cruz, Calif.); Mejía-Arauz, R. (Guadalajara)

\section{KARGER}

E-Mail karger@karger.com www.karger.com
(C) 2015 S. Karger AG, Basel

Access to full text and tables of contents, including tentative ones for forthcoming issues: www.karger.com/hde_issues
96 Children's Initiative in Contributions to Family Work in Indigenous-Heritage and Cosmopolitan Communities in Mexico

Alcalá, L.; Rogoff, B. (Santa Cruz, Calif.); Mejía-Arauz, R. (Guadalajara); Coppens, A.D.; Dexter, A.L. (Santa Cruz, Calif.)

116 Children's Initiative in Family Household Work in Mexico

Coppens, A.D.; Alcalá, L. (Santa Cruz, Calif.); Mejía-Arauz, R. (Guadalajara); Rogoff, B. (Santa Cruz, Calif.)

131 One, Two, Three, Eyes on Me! Adults Attempting Control versus Guiding in Support of Initiative

Paradise, R.; Mejía-Arauz, R.; Silva, K.G.; Dexter, A.L.; Rogoff, B. (Santa Cruz, Calif.)

150 Learning by Observing and Pitching In: Benefits and Processes of Expanding Repertoires

Coppens, A.D.; Silva, K.G.; Ruvalcaba, O.; Alcalá, L.; López, A.; Rogoff, B. (Santa Cruz, Calif.)

Commentary

162 Children Learning by Observing and Pitching In: Commentary

Ochs, E. (Los Angeles, Calif.)

No. 4

Editor's Corner

173 What Do We Know about Sensitive Periods in Human Development and How Do We Know It? Fox, N.A. (College Park, Md.)

Original Paper

176 An Evaluation of Ethnicity Research in Developmental Psychology: Critiques and Recommendations

Gjerde, P.F. (Santa Cruz, Calif.)

Commentaries

206 How Can Developmentalists Deepen Theory and Research on Ethnicity? Commentary on Gjerde Holloway, S.D.; Kunesh, C.E. (Berkeley, Calif.)

213 Ethnicity and Ethnic Identity in Context Commentary on Gjerde Kiang, L. (Winston-Salem, N.C.)

Original Paper

222 An Analysis of the Conceptual Foundations of the Infant Preferential Looking Paradigm Tafreshi, D.; Thompson, J.J.; Racine, T.P. (Burnaby, B.C.) 
Commentaries

241 Definitions and Developmental Processes in Research on Infant Morality.

Commentary on Tafreshi, Thompson, and Racine Dahl, A. (Berkeley, Calif.)

250 The Conceptual and Empirical Case for Social Evaluation in Infancy.

Commentary on Tafreshi, Thompson, and Racine Hamlin, J.K. (Vancouver, B.C.)

\section{No. 5}

Original Paper

259 What Does Healthy Sex Look Like among Youth? Towards a Skills-Based Model for Promoting Adolescent Sexuality Development Arbeit, M.R. (Medford, Mass.)

Commentaries

287 Sexuality Development in Adolescence and Beyond. Commentary on Arbeit

Moshman, D. (Lincoln, Nebr.)

292 Expanding the Scope of a Dynamic Perspective on Positive Adolescent Sexual Development.

Commentary on Arbeit

Diamond, L.M. (Salt Lake City, Utah)

Essay Reviews

305 Timescales and Adaptation in Children's Typical and Atypical Development: A Functionalist Approach.

Essay Review of Children and Emotion: New Insights into Developmental Affective Science edited by Kristin Hansen Lagattuta

Barrett, K.C. (Fort Collins, Colo.)

313 It Takes a Family to Raise a Child. Review of Romania's Abandoned Children:Deprivation, Brain Development, and the Struggle for Recovery by Charles A. Nelson, Nathan A. Fox, and Charles H. Zeanah

Fisher, P.A. (Eugene, Oreg.)
No. 6

Editor's Corner

319 The Politics of Development

Barber B.K. (Washington, D.C/Knoxville, Tenn.)

Original Paper

322 The Study of Character Development: Towards Tests of a Relational Developmental Systems Model Lerner, R.M.; Schmid Callina, K. (Medford, Mass.)

Commentaries

347 Toward a Relational-Developmental Model of Character Development.

Commentary on Lerner and Schmid Callina

Mascolo, M.F. (North Andover, Mass.)

354 Quantum Character.

Commentary on Lerner and Schmid Callina

Berkowitz, M.W. (St. Louis, Mo.)

Essay Review

360 Broken Compass or Broken System? Questioning the Role of Parent Involvement in Promoting Student

Achievement. Essay Review of The Broken Compass: Parental Involvement with Children's Education by Keith Robinson and Angel Harris Holloway, S.D.; Park, S. (Berkeley, Calif.)

364 Acknowledgement 